\title{
Names in some Works of Malaparte
}

\author{
JOHN VAN EERDE
}

Udzio Malaparte's works are noteworthy for the many names strewn through their pages. This article would suggest that the presence of these names is not a fortuitous circumstance, but rather a stylistic procedure of some importance. The article will address itself particularly to La Pelle. ${ }^{1}$

Through reference to names, especially those associated with literary history, Malaparte consistently economizes in his descriptive passages, and forces the reader to form the picture evoked by a literary association rather than by the novelist himself. An example of this is his allusion to the encounter of the homosexuals residing in Italy during World War II: "Si riconoscevano all'odore, a un accento, a uno sguardo: e con un alto grido di gioia si gettavano gli uni nelle braccia degli altri, come Virgilio e Sordello nell' Inferno di Dante, facendo risuonare le vie di Napoli delle loro morbide, e un po' rauche, voci femminili" (p. 108). ["They recognized each other by a scent, by an accent, by a look: and with a loud shout of joy would throw themselves into each other's arms, like Vergil and Sordello in Dante's Inferno, making the streets of Naples resound with their morbid and rather raucous feminine voices."] The mention of the meeting of Vergil and Sordello is obviously designated to enable the reader to enlarge Malaparte's image. There is a similar procedure in the description of Hamburg after a saturation bombing: "Per alcuni giorni Amburgo offrì l'aspetto di Ditte, la cittâ infernale" (p. 132). ["For a few days Hamburg looked like Ditte, the city of Hell."]

Malaparte employs this method often enough to allow one to recognize in him a considerable unwillingness to create an autonomous imagery. What he seems consistently to do is to suggest

1 Curzio Malaparte, La Pelle (Rome, 1949). References to pages, made within the text, will be to this edition. 
pictures in the reader's mind through the evocative power of names. This is evident in his attempt to communicate the intellectual climate of a certain group in Italy during the war: "... i giovani recitano oggi la parte d'invertiti come, al tempo di Byron e di Musset, recitavan quella di eroi romantici, o, più tardi, quella di poeti maledetti, e più recentemente la parte di raffinati Des Esseintes" (p. 165). ["Youths today play the part of inverts as, in the time of Byron and Musset they played that of romantic heroes, or later, that of decadent poets, and more recently the part of refined Des Esseinteses."]

In the above passage, names are used to characterize periods of history. They are in fact Malaparte's chief characterizing agent. This is particularly true in the case of his description of language. By a list of names Malaparte will hope to enable his reader to hear the tongue spoken by certain people in his writings. The already mentioned homosexuals speak a language of which Malaparte has little to say directly, but which he likens to that of René, of Giraudoux, of Baudelaire, in what he calls a Stravinskian transcription of Proust "pieno di quelle cadenze affettuose e maligne che rievocano il tiepido clima di certi 'interni' proustiani, di certi paesaggi morbosi, tutto l' autunno di cui è ricca la stanca sensibilitâ degli omosessuali moderni. Essi stonavano, parlando in francese, non già come si stona nel canto, ma come si stona parlando in sogno: posavano l'accento fra una parola e l'altra, come fan Proust, Giraudoux, Valéry" (pp. 109-110). ["full of those affettuoso and sly cadenzas which conjure up the warm climate of certain Proustian 'interiors,' of certain morbose landscapes, the whole autumn that enriches the tired sensibility of modern homosexuals. Speaking French, they were out of tune, not as one is in singing, but as one is when talking in a sleep: they would put the stress between one word and another, as Proust, Giraudoux, and Valéry do.'] Thus Malaparte identifies a manner of speech with a name which evokes a literary style. Early in La Pelle Jack says he learned French from his concierge and from La Fontaine: "Tu ne trouve pas que je parle comme les animaux de La Fontaine? Ho imparato da lui 'qu' un chien peut bien regarder un Evêque"” (pp. 22-23). ["Don't you think I speak like La Fontaine's animals? I learned from him 'that a dog can certainly look at a Bishop."'] French is not the only language described in an indirect fashion by this writer. In the case of English 
he will again have recourse to names. He says that Walter de la Mare's English is like an ancient music, like Rupert Brooke's, the tongue of the last humanistic tradition of Edwardian England. And the Oxford accent of Fred, a character in La Pelle, is heard as a "frisson module" ["A modulated shudder"], the term used, Malaparte tells us, by Gerard de Nerval to desribe Silvia's speech. Finally the previously mentioned homosexual group is said by the author to have spoken an English reminiscent of the Elizabethan sonnets and of passages uttered by certain of Shakespeare's characters in the comedies. Of course he names them: Theseus (opening Midsummer Night's Dream with "O, me thinks, how slow this old moon wanes!") or Hippolyta (saying "Four nights will quickly dream away the time") or Orsino (guessing Viola's sex in Twelfth Night).

As might be expected names figure prominently whenever Malaparte is describing people in an intellectual environment or as the product of a certain intellectual climate. He writes of a German woman in La Pelle thus: "Gerda Von $\mathrm{H}$... pareva muoversi e respirare in quel paesaggio convenzionale della poesia di Stephan George, dove le architteture neoclassiche di Winckelmann e gli scenari del secondo Faust fanno da sfondo alle spettrali Muse di Hölderlin e di Rainer Maria Rilke" (p. 136). ["Gerda Von H ... seemed to move and breathe in that conventional landscape of Stephan George's poetry, in which the neoclassic architecture of Winckelmann and the scenarios of the second Faust act as a background for the spectral Muses of Hölderlin and Rainer Maria Rilke."] It is through reference to their readings that we are acquainted with the intellectual make-up of the homosexuals in La Pelle. Malaparte tells us that they looked for inspiration to Gide (who was their Goethe) and read André Breton, Paul Elouard, Sartre and Pierre-Jean Jouve.

This indirect method of characterization through names may involve more than one intermediary between the personage characterized and Malaparte's reader. For example, Jack in La Pelle is presented as being unlike the Americans in Paris in Hemingway's The Sun Also Rises. But the characterization does not stop there. Malaparte compounds the effect by adding that Hemingway's Americans were like those of Eleanor Green, of whom Sinclair Lewis once wrote that they were "Come i profughi intellettuali della Rive Gauche 
verso il 1925, o come T. S. Eliot, Ezra Pound, o Isadora Duncan, iridescent flies caught in the black web of an ancient and amoral european [sic] culture" (p. 26). ["Like the intellectual refugees of the Left Bank about 1925, or like T. S. Eliot, Ezra Pound, or Isadora Duncan ..."] Even when Malaparte ventures a description of his own, he often invokes the name of a literary figure as a kind of ultimate confirmation. Thus he compares Italy's wartime homosexuals to Americans in Paris in the 1920's “... i cui visi appannati dall'alcool e dalle droghe appaiono incastrati l'uno nell'altro, come in un quadro bizantino, nella galleria dei personaggi dei primi romanzi di Hemingway ..." (p. 26). ["... whose faces dulled with alcohol and drugs seem wedged together, as in a byzantine painting, in the gallery of characters in Hemingway's first novels ..."']

As can be seen, Malaparte has much to say about these inverts in La Pelle. He shows them meeting each other as Vergil and Sordello met, he describes their intellectual orientation in terms of several French writers whom he names. He pictures their physical appearance in the light of Hemingway. He also alludes to what he calls their bourgeois aestheticism, and his definition of this is again a series of names. Here, as elsewhere, Malaparte would seem to aim at a cumulative effect, as he finds their above mentioned aestheticism based on a group of writers including Novalis, the comte de Lautréamont, Wilde, Diaghilev, Rilke, D'Annunzio, Gide, Cocteau, Proust, Maritain, Apollinaire, Valéry and Barrès. He adds that later the homosexuals turned to Marx and the Soviet writer, Simonov.

The examples of Malaparte's use of names to characterize, given above, involve groups or members of agroup forming a kind of collectivity. ${ }^{2}$ However, the same process is evident where the writer deals with an individual. Jack in La Pelle is described as inebriated, confusing Horace and Poe and putting Annabel Lee and Lydia in the same stanza. This is the Jack "Che conosceva tutto Rimbaud a memoria" (p. 45). ["Who knew all of Rimbaud by heart]. It is Jack whose kneeling on the sand at the Salerno landings prompts Malaparte to evoke Aeneas' arrival at the mouth of the Tiber.

${ }^{2}$ Gerda Von H... is not an exception, as we meet her in a group with which she quickly identifies herself. 
We see the same dependence on literary reference in the comparison of Conseulo to the women "dai capelli trasparenti del color dell' ala delle cicale, che nelle commedie di Fernando de Rojas e di Gil Vicente parlano in piedi, con lunghi gesti e lenti" (p. 299). ["with transparent hair the color of the harvest-fly's wing, who in the plays of Fernando de Rojas and Gil Vicente stand talking with slow, sweeping gestures."]

Similarly Malaparte compares Consuelo to women "... dai capelli del colore del miele freddo, che nelle commedie di Lope de Vega, di Calderón de la Barca, di Ramon de la Cruz, parlano con voce stridula, camminando in punta di piedi ... Anche Consuelo ha 'los ojos graciosos' della canzone di Melibea e di Lucrezia nella Celestina, che umiliano "los dulces árboles sombrosos"" (p. 299). [..."with hair the color of cold honey, who in the plays of Lope de Vega, of Calderón de la Barca, of Ramon de la Cruz, speak in a shrieking voice, walking on tip-toe. Consuelo too has 'the attractive eyes' of the song of Melibea and Lucretia in the Celestina, which humble 'the sweet, shady trees." "] The procedure is repeated in his comparison of Mrs. Fiat in La Pelle to Toutchevitch "quel personaggio di Anna Karenina di Tolstoi, che era dello stesso stile Luigi XV del salotto della Principessa Betsy Tverskaia' (p. 258). ["that character in Tolstoy's Anna Karenina, who was the same Louis XV style as Princess Betsy Tverskaia's drawing-room.'] Jeanlouis in La Pelle is handsome in a way that elicits names: "Era, quella di Jeanlouis, la romantica bellezza virile che piaceva a Stendhal, la bellezza di Fabrizio del Dongo. Aveva la testa di Antinoo ..." (p. 122). ["Jeanlouis' beauty was the virile, romantic beauty that Stendhal liked, Fabrizio del Dongo's beauty. He had Antinoo's head."'] The use of names in this instance is of particular interest in that the reader is placed two steps away from the quality of Jeanlouis' good looks. This quality is not merely that of the beauty of Fabrizio del Dongo, but specifically what pleased Stendhal in it. This relationship becomes important as Malaparte goes on to establish a parallel. "Quegli ufficiali francesi erano Stendhal di fronte a Fabrizio del Dongo. E anch' essi, come gì Stendhal, non avertivano che la belleza di Jeanlouis era, come quella di Fabrizio, una belleza senza ironia, e senza inquietudini di natura morale" (p. 152). ["Those French officers were Stendhal facing Fabrizio Dongo. And they too, as Stendhal, paid no attention to the fact 
that Jeanlouis' beauty was, like that of Fabrizio, without irony and without any preoccupations of a moral nature."']

Malaparte applies his method of characterization not only to animate beings, but also to inaminates. Describing the sea as winecolored, he remarks that this is the way it looks in Homer. And his Rome glistens in the Sun "Simile a quelle città di pietra chiara che appaiono in fonda all'orizzonte nei paesaggi dell' Illiade" (p. 336). ["Like those cities of bright stone that appear deep on the horizon of the landscapes in the Iliad."'] He thinks of a house once visited from time to time by Pierre Lyautey in terms of names: Napoleon (he had a room there) Stendhal (he and Angela Pietragrua shared and hence immortalized a bed there), and Parini (he wrote his poem "Il Giorno" on a desk in the house).

Malaparte's preoccupation with names is particularly striking in La Pelle, but it is not new with that work. An enumeration of names serves to describe Paris in Kaputt: “... quella sua giovane Parigi, di Puvis de Chavannes, dei suoi amici pittori, Zorn, Wahlberg, Cederström, Arsenius, Wennerberg, di quei suoi anni felici. 'Paris était bien jeune, alors.' Era la Parigi di Madame de Morienval, di Madame de Saint-Euverte, della Duchessa di Luxembourg (e anche di Madame de Cambremer e del giovane Marchese di Beausergent), di quelle stesse déesses di Proust -" (pp. 48-49). ${ }^{3}$ ["... his young Paris, the Paris of Puvis de Chavannes, of his painter friends, Zorn, Wahlberg, Cederström, Arsenius, Wennerberg, of his happy years. 'Paris was very young then.' It was the Paris of Madame de Morienval, of Madame de Saint-Euverte, of the Duchess of Luxemburg (and also of Madame de Cambremer and of the young Marquis de Beausergent), of those same goddesses of Proust ..."] Paris furnishes a continued application of the method as Malaparte proceeds:

Sulle immagini della remota Parigi di Madame de Guermantes e del Principio Eugenio, si sovrapponevano a poco a poco, davanti ai miei occhi, le dolorose e care immagini di una Parigi più giovane, più torbida, più inquieta, più triste, forse. Come i visi dei passanti che affiorano dalla nebbia di là dai vetri di un caffè, io vedevo affacciarsi alla memoria i volti di Albertine, di Odette, di Robert de Saint Loup,

${ }^{3}$ Curzio Malaparte, Kaputt (Naples, 1944). References to pages, made within the text, will be to this edition. 
le ombre degli adolescenti che s'intravedono dietro le spalle di Swan e di M. de Charlus, le fronti segnate dall'alcool, dall' insonnia, e dalla sensualità, dei personaggi di Apollinaire, di Matisse, di Picasso, di Hemingway, gli spettri azzurri e grigi di Paul Elouard (pp. 51-52).

[On the images of the remote Paris of Madame de Guermantes and of Prince Eugene, there were gradually superimposed before my eyes, the sad and dearimages of a younger, more troubled, a sadder Paris, perhaps. Like the faces of passersby that appear out of the mist from the other side of a café window, I could see looming in my memory the faces of Albertine, Odette, Robert de Saint Loup, the shades of the adolescents partially seen behind the backs of Swan and M. de Charlus, their foreheads marked with the alcohol, insomnia, and sensuality of the characters of Apollinaire, Matisse, Picasso, Hemingway, the blue and grey spectres of Paul Elouard."]

A city, a whole country may be summed up in a name as Malaparte tells us, writing, "Parigi, per Victor Maurer, era il bar del Ritz, e la Francia era il suo amico Pierre Cot" (p.516). ["Paris, for Victor Maurer, was the Ritz bar, and France was his friend Pierre Cot."']

It is not surprising that the Russian village of Alexandrowska should evoke a comment from Malaparte bearing on its name: "In Russia, i villaggi si assomigliano tutti, anche nel nome. Ci son molti villaggi che hanno il nome di Alexandrowska, nella regione di Balta" (p. 54). ["In Russia all villages resemble each other even as to name. There are many villages with the name Alexandrowska, in the region of Balta."]

The importance that Malaparte attaches to names as words used to designate persons or institutions is nowhere more clearly seen than in his fascinating comparison of Mussolini with Lord Perth. He notes their manner of speech as revealed, significantly enough, in their pronunciation of names. Mussolini sounded like a peasant of Romagna, saying "scopone," "Lambrusco," "Comizio," and "Forlì," when pronouncing such words as Mediterranean, Suez, Ethiopia, while Lord Perth pronounced the same words as he would the Serpentine, Whiskey, and Edinburgh. ${ }^{4}$

4 Names are not the only term of comparison here, but they are much in evidence. 
As has been stated, Malaparte's dedication to names was a longstanding one. In Don Camalè (1928) there are already examples of names in enumeration, resulting in a kind of cumulative effect. ${ }^{5}$ For example, he writes: "Se l'Italia di questi anni fosse la Francia dell' ottantanove, e se i partigiani del governo di Ottobre avessero avuto a che fare con: Les Actes des Apôtres, con i due Rivarol, Suleau, Champcenetz, Mirabeau, 'Le Vicomte' Peltier, Bergasse, Monlosier, Lauragnais, Tilly, de Bonnay, Barruel-Bauvert, sareberro morti tutti quanti di paura" (p.125). [If the Italy of these years were the France of ' 89 and if the October Government partisans had had to deal with The Acts of the Apostles, with the two Rivarols, Suleau, Champenetz, Mirabeau, 'Le Vicomte' Peltier, Bergasse, Monlosier, Lauragnais, Tilly, De Bonnay, Barruel-Bauvert, the whole lot would have died of fright."']

There is in the Camalèo the same use of a name to characterize as is seen in La Pelle and Kaputt. At one point Sebastiano remarks to his pupil Don Camalèo that Italy no longer has any courtiers left. There are only poultry in the courtyard of Rome. Don Camalèo asks whether these are animals such as one finds in Phaedrus: " 'Come quelli di La Fontaine, piuttosto' replicò Sebastiano cambiando discorso" (p. 89). ["Like those of La Fontaine rather' replied Sebastiano changing the conversation."] And on another page Don Camalèo complains that people treat him like a man who resembles an animal: " 'O come una specie di Scarron' interloquiva Sebastiano" (p. 127). ["'Or like a kind of Scarron' interjected Sebastian. It is natural in the same novel to find the author referring to Lamartine's characterization of Talleyrand as a muted Mirabeau in preface to his own characterization of the Italian people as "... tutti dei Machiavelli a mezza voce" (p. 175). ["...All muted Machiavellis."] And consistent with Malaparte's use of names to replace descriptive adjectives is his allusion to "Quello strano e magro personaggio alla Balzac" (p. 135). ["That odd, thin personage à la Balzac.'] Indeed the whole book Don Camalèo, bitterly satirical of the prattling conqueror of defenseless Ethiopia, is an eloquent witness to Malaparte's emphasis on names. The name "Mussolini" seems to occur on almost every page of the novel.

5 Curzio Malaparte, Don Camalè (Florence, 1946). References to pages, made within the text, will be to this edition. 
In the twelve pages of Chapter XXI "L'Uomo et la bestia," the name occurs thirty-four times.

The effect of Malaparte's use of names as a characterizing agent is to make his style a hurried one. It also injects a distinct superficiality to his descriptions. Quite aside from such inaccuracies as placing the meeting of Vergil and Sordello in the Inferno rather than in the Purgatorio, Malaparte sometimes calls on names for what they do not have to give. There is, for instance, no such instinctive recognition in the Vergil-Sordello meeting as in that of the homosexuals of La Pelle. Only when Sordello hears the word "Mantova" does he say "O Mantovano, io son Sordello de la tua terra." ["O Mantouan, I am Sordello from your land."']

Malaparte's avalanche of names tends to neglect the valid distinctions and nuances of literary criticism. Too many of them are used at the same time to qualify a person, a place, or an object. Only rarely does the author acknowledge chronology and the difference between generations, as for instance, when he writes: "Quel che appariva strano era il fatto che Barrès era altrettanto lontano da Jeanlouis e dai giovani della sua generazione quanto Gide: il Gide di 'moi, cela m'est égal, parce que j'écris Paludes'" La Pelle, p. 153). ["What appeared strange was the fact that Barrès was as far from the youth of his generation as Gide: the Gide of 'To me that makes no difference, because I wrote Paludes."']

This super-abundance is often self-defeating. One thinks of what Malaparte himself wrote in a novel: "Sebastiano aveva regione: lo scolaro pretendeva troppi maestri. Ora andava matto per l' autore del Dizionario filosofico, ora per Bossuet. Plutarco lo inamorò per una settimana, Amleto gli tolse sonno di due notti; finì per disgustarsi di Amleto leggendo Laforgue (Don Camalèo, p. 87). ["Sebastian was right: the pupil aspired to too many masters. Now he would go mad for the author of the Philosophical Dictionary, now for Bossuet. Plutarch enamoured him for a week, Hamlet cost him two nights sleep; he finally became disgusted with Hamlet reading Laforgue."]

The Universit of Rhode Island

Kingston, R. I. 